
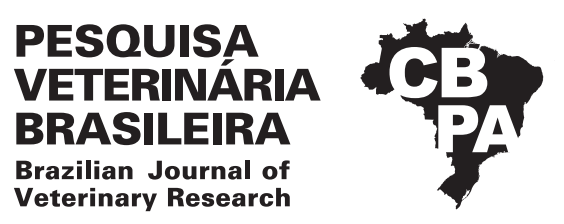

Pesq. Vet. Bras. 38(11):2166-2174, novembro 2018 DOI: $10.1590 / 1678-5150-P V B-5707$

Original Article

ISSN 0100-736X (Print)

ISSN 1678-5150 (Online)

\title{
Histological characterization of reproductive tract and fetal annexes of the West Indian Manatee (Trichechus manatus) from Brazil ${ }^{1}$
}

\author{
Arielle R. Bezerra², Carminda S.B. Salmito-Vanderley², Paulo R.O. Bersano², \\ Vitor L. Carvalho ${ }^{3}$, Ana C.O. Meirelles ${ }^{3}$, Fernanda L.N. Attademo ${ }^{4}$, Fábia O. Luna ${ }^{4}$ \\ and Lúcia D.M. Silva ${ }^{2 *}$
}

\begin{abstract}
Bezerra A.R., Salmito-Vanderley C.S.B., Bersano P.R.O., Carvalho V.L., Meirelles A.C.O., Attademo F.L.N., Luna F.O. \& Silva L.D.M. 2018. Histological characterization of reproductive tract and fetal annexes of the West Indian Manatee (Trichechus manatus) from Brazil. Pesquisa Veterinária Brasileira 38(11):2166-2174. Universidade Estadual do Ceará, Avenida Dr. Silas Munguba 1700, Campus do Itaperi, Fortaleza, CE 60714-903, Brazil. E-mail: lucia.daniel.machado@hotmail.com

The West Indian manatee (Trichechus manatus) is one of the most threatened aquatic mammals in Brazil, and is currently classified as "endangered" (MMA). The objective of this study was to characterize histologically the reproductive tract and fetal annexes of stranded manatees in northeastern Brazil. Tissue samples were collected from the reproductive tract of 23 manatees, which were fixed in $10 \%$ buffered formalin, processed using standard histological protocols and stained with hematoxylin eosin. We qualitatively described the histological and histomorphometric characteristics of each structure. Six ovaries were analyzed. In four ovaries, we found a large number of primordial and primary follicles. Two ovaries were different from the others: one had inflammatory infiltration and the other had a thickening in the cortex and absence of follicles. We also analyzed seven uteri (of which four were in the proliferative phase, two in the secretory phase, and one in the recovery phase), four placentas, one vagina, six testes (four were in the immature phase, one in the pubertal phase, and one in the mature phase), two epididymides, two penises, and one umbilical cord. The histological and morphometric findings in our work will support future analyses of the reproductive tract of T. manatus from Brazil.
\end{abstract}

INDEX TERMS: Histology, reproductive tract, fetal annexes, West Indian Manatee, Trichechus manatus, Brazil, sirenian, reproductive biology, embryonic annexes.

RESUMO.- [Caracterização histológica do trato reprodutor e anexos fetais do peixe-boi marinho (Trichechus manatus) do Brasil.] O peixe-boi marinho (Trichechus manatus) é um dos mamíferos aquáticos mais ameaçados do Brasil e, atualmente é classificado como "em perigo" (MMA).

\footnotetext{
${ }^{1}$ Received on December 7, 2017.

Accepted for publication on March 26, 2018.

${ }^{2}$ Post-Graduate Program in Veterinary Science, Universidade Estadual do Ceará, Avenida Dr. Silas Munguba 1700, Campus do Itaperi, Fortaleza, CE 60714-903, Brazil. *Corresponding author: lucia.daniel.machado@hotmail.com

${ }^{3}$ Associação de Pesquisa e Preservação de Ecossistemas Aquáticos (Aquasis), Av. José Alencar 150, Praia de Iparana, Caucaia, CE 61627-210, Brazil.

${ }^{4}$ Centro Nacional de Pesquisa e Conservação de Mamíferos Aquáticos (CMA-ICMBio), Estrada do Forte Orange s/n, Pilar, Ilha de Itamaracá, PE 53900-000, Brazil.
}

O objetivo deste estudo foi caracterizar histologicamente o trato reprodutor e os anexos fetais de peixes-bois marinhos encalhados no Nordeste do Brasil. Foram coletadas amostras de tecidos do trato reprodutor de 23 peixes-bois marinhos (T. manatus), que foram fixadas em formol tamponado a $10 \%$, processados usando protocolos histológicos padrão e corados com hematoxilina eosina. Foi realizada a descrição qualitativa das características histológicas e histomorfométricas de cada estrutura. Foram analisados seis ovários. Em quatro ovários, foi encontrado um grande número de folículos primordiais e primários. Dois ovários eram diferentes dos outros: um tinha infiltração inflamatória e o outro tinha um espessamento no córtex e ausência de folículos. Também foram analisadas sete amostras uterinas (das quais quatro estavam na fase proliferativa, duas na fase secretória e uma 
na fase de recuperação), quatro placentas, uma vagina, seis testículos (quatro na fase imatura, um na fase puberal e um na fase madura), dois epidídimos, dois pênis e um cordão umbilical. Os achados histológicos e morfométricos em nosso trabalho apoiarão futuras análises do trato reprodutivo de T. manatus do Brasil.

TERMOS DE INDEXAÇÃO: Histologia, trato reprodutor, anexos fetais, peixe-boi marinho, Trichechus manatus, Brasil, sirênio, biologia reprodutiva, anexos embrionários.

\section{INTRODUCTION}

The population of manatees (Trichechus manatus) in the Brazilian Northeast has been estimated to range from 485 to 2,221 individuals, based on overflight measurements, which indicates that there are few manatees in this region (Alves et al. 2016). This species represents one of the most endangered aquatic mammals in Brazil, and is classified as "endangered" in the Official National List of Endangered Species (Brasil 2014).

Some issues faced by the manatee population of the Brazilian Northeast include the rapid growth of anthropogenic activities in the coastal zones, habitat destruction owing to the loss of mangroves, estuarine sedimentation (leading females to have their offspring in more agitated waters, risking the cubs to be carried away by tides and stranded on beaches), water pollution, and debris ingestion; because manatees have coastal habits and this area has a higher concentration of litter (Parente et al. 2004, Meirelles 2008, Lima et al. 2011, Attademo et al. 2015).

To develop effective conservation strategies for endangered species, such as the manatee, it is crucial to understand their life history and reproductive biology (Marsh et al. 2011). Studies on manatees from the United States, where a large number of dead animals were evaluated, resulted in an analysis of the reproductive tracts of males and females (Hernandez et al. 1995, Marmontel 1995). According to these authors, male manatees present a vascular penis that retracts when not engorged, do not have a crotch, have intra-abdominal testicles (with a ventrolateral position to the kidneys), and bilateral seminal vesicles, which are in a dorsal position in relation to the urinary bladder. However, the prostate is composed of erectile muscle tissue (Reynolds III et al. 2002).

Regarding the females, their reproductive system is composed of ovaries, uterine tubes, uterus, vagina, vaginal vestibule, and clitoris. The mammary glands also contribute to the reproductive process. Female manatees have a bicornuate uterus, and with a zonary (anatomical classification) and endotheliochorial (histological classification) placenta (Rodrigues et al. 2008).

Although this species has been studied for more than three decades, research on its reproductive system has not yet been performed in Brazil. The histological evaluation of the reproductive system has been carried out by the analysis of samples collected from stranded dead animals. However, access to these types of samples has been limited in Brazil because as the small size of the population, the high frequency of newborn stranding, the stage of decomposition of dead stranded individuals and the storage of samples in the collections (Meirelles \& Carvalho 2016).

Thus, the objective of this study was to characterize the reproductive tract and fetal annexes of male and female manatees stranded in northeastern Brazil to support future studies on the age of sexual maturation in these animals.

\section{MATERIALS AND METHODS}

Ethical aspects. This experiment was approved by the Ethics Committee for Animal Use of the State University of Ceará (number 0971110/2016) and the Biodiversity Authorization and Information System (SISBIO)/Chico Mendes Institute for Biodiversity Conservation (ICMBio, license number 51456-3).

Animals. We analyzed tissue samples from the reproductive tracts of 23 manatees (Trichechus manatus Linnaeus, 1758), including 14 females and 9 males of different age groups. These animals were stranded, died in rehabilitation, or gave birth in captivity from July 1995 to October 2016 (Tables 1 and 2). Manatees were necropsied according to conventional protocols (Geraci et al. 2005). Samples were included in the biological collections of the Association for Research and Preservation of Aquatic Ecosystems (Aquasis) in Caucaia, Ceará and the National Center for Research and Conservation of Aquatic Mammals (CMA/ICMBio) in Itamaracá, Pernambuco.

Histological processing. Tissues from the reproductive tracts were fixed in $10 \%$ buffered formalin. We collected tissue samples approximately $2 \mathrm{~cm}$-thick and processed them using standard histological protocol before histological staining with hematoxylin eosin (HE). Slides containing the processed samples were analyzed using light microscopy. During the histological processing, samples were dehydrated through successive washing in alcohol solutions with gradually increased concentrations $(70,80,95$, and 100\%). Samples were washed for 50 min with each solution and then maintained in an alcohol/xylol solution for $24 \mathrm{~h}$. Thereafter, samples were diaphanized, where they were successively placed in two xylol solutions for $50 \mathrm{~min}$ each. They were then subjected to an inclusion process, in which samples were impregnated with two sets of paraffin for $50 \mathrm{~min}$ at $60^{\circ} \mathrm{C}$. We then embedded the biological material in histological paraffin.

The embedded samples were cut into $5 \mu \mathrm{m}$-thick sections using a histological resin microtome (Leica RM 2235). Sections were then immersed in a histological water bath at a mean temperature of $45^{\circ} \mathrm{C}$ and collected on slides pre-prepared with albumin. The slides containing the sections were maintained in an oven (MD 1.2) for sterilization and drying. Next, the slides were histologically stained with hematoxylin eosin. Fragments of testis, penis, umbilical cord, and placenta tissue were later stained with Masson's trichrome.

After this procedure, slides were analyzed using light microscopy and were photomicrographed (Nikon Eclipse 80i) using a digital photomicrographic system (Nikon NIS-Elements Advanced Research). During the analysis, we qualitatively described the histological and histomorphometric characteristics of each structure: a) ovaries (cortex thickness, largest and smallest diameter of the follicles with an observable oocyte); b) uterus (thickness of mucosa and endometrium); c) vagina (thickness of the vaginal epithelium), and d) testicles (major and minor diameter of the seminiferous tubules). The analysis was performed using Image J software, with an average of ten measurements for each structure.

Statistical analysis. Subjective data were presented in descriptions, whereas objective data were expressed as mean \pm standard deviation. 
Table 1. Information on the female manatees (Trichechus manatus) analyzed

\begin{tabular}{|c|c|c|c|c|c|}
\hline Register number & $\begin{array}{c}\text { Date of stranding } \\
\text { or death }\end{array}$ & Place of stranding & $\begin{array}{l}\text { Total length } \\
\text { (meters) }\end{array}$ & Age group & Samples \\
\hline 02S0112/31 & $14 / 11 / 2005$ & Fontaínhas, Aracati/CE & 3.15 & Adult & Uterus \\
\hline 02S0112/36 & $26 / 09 / 2006$ & Between Redonda and Peroba, Icapuí/CE & 3.07 & Adult & Ovary \\
\hline 02S0112/38 & $25 / 02 / 2007$ & Retiro Grande, Icapuí/CE & 3.18 & Adult & Uterus \\
\hline 02S0112/57 & $19 / 10 / 2012$ & Canto Verde, Beberibe/CE & 1.20 & Calf & Uterus \\
\hline 02S0112/60 & $21 / 09 / 2013$ & Retirinho, Aracati/CE & 2.41 & Adult & Ovary \\
\hline 02S0112/77 & $17 / 10 / 2016$ & Ponta Grossa, Icapuí/CE & 3.18 & Adult & Ovary \\
\hline 08S0112/20 & $24 / 03 / 2015$ & Alagamar, Grossos/RN & 1.20 & Calf & Ovary and uterus \\
\hline 01S0112/02 & $21 / 01 / 2008$ & Barro Preto/CE & 3.07 & Adult & Placenta \\
\hline 01S0112/07 & $08 / 06 / 2007$ & Ponta de Pedra/PE & 2.90 & Adult & Placenta \\
\hline 01S0112/08 & $30 / 07 / 2008$ & Barra de Sucatinga, Beberibe/CE & 2.89 & Adult & Placenta \\
\hline 01S0112/12 & 28/07/1995 & Jacarecica, Maceió/AL & 1.08 & Calf & Ovary, uterus and vagina \\
\hline 01S0112/25 & $11 / 04 / 2008$ & Born in captivity, 10/4/97, PE & 2.59 & Adult & Placenta \\
\hline 01S0112/30 & $10 / 11 / 1999$ & Barra de Camaratuba/PB & 1.36 & Calf & Uterus \\
\hline 01S0112/31 & 02/03/1998 & Pitimbi/PB & - & - & Ovary and uterus \\
\hline
\end{tabular}

The age group was defined according to Marmontel (1995).

Table 2. Information on the male manatees (Trichechus manatus) analyzed

\begin{tabular}{|c|c|c|c|c|c|}
\hline Register number & $\begin{array}{c}\text { Date of stranding } \\
\text { or death }\end{array}$ & Place of stranding & $\begin{array}{l}\text { Total length } \\
\text { (meters) }\end{array}$ & Age group & Samples \\
\hline 02S0111/42 & $13 / 02 / 2008$ & Redonda, Icapuí/CE & 1.19 & Calf & Testicles \\
\hline 02S0111/45 & $10 / 10 / 2008$ & Parajuru, Beberibe/CE & 1.15 & Calf & Testicles \\
\hline 02S0111/55 & $23 / 09 / 2011$ & Ponta Grossa, Icapuí/CE & 2.01 & Juvenile & Testicles \\
\hline 02S0111/59 & $23 / 03 / 2013$ & Manibu, Icapuí/CE & 1.08 & Calf & Testicles and epididymis \\
\hline 02S0111/71 & $05 / 03 / 2015$ & Ariós, Beberibe/CE & 1.35 & Calf & Epididymis \\
\hline 02S0111/73 & $03 / 10 / 2015$ & Ponta Grossa, Icapuí/CE & 3.01 & Adult & Testicles and penis \\
\hline 01S0111/123 & $04 / 11 / 2002$ & Born in captivity/PE & 1.06 & Calf & Testicles \\
\hline 01S0111/180 & $24 / 12 / 2004$ & Barretas, Nisia Floresta/RN & 2.72 & Adult & Penis \\
\hline 01S0111/304 & $16 / 11 / 2011$ & Born in captivity/PE & 0.79 & Calf & Umbilical cord \\
\hline
\end{tabular}

The age group was defined according to Marmontel (1995).

\section{RESULTS}

We analyzed six ovaries, two of which were different from the others. We also analyzed seven uteri, four placentas, one vagina, six testicles, two epididymides, two penises, and one umbilical cord. These tissues were collected from manatees of different sizes and age groups (Table 1 and 2).

\section{Ovaries}

The ovary was coated with a serum layer consisting mainly of simple cubic epithelium, which, in some cases, had features of pseudostratified epithelium or small areas of columnar epithelium (Fig.1A).

The ovarian cortex consisted of a narrow band (Table 3) with the presence of follicles surrounded by supporting tissue. In manatees 08S0112/20, 01S0112/12, and 01S0112/31, there was a predominance of primordial follicles, but some primary follicles were also observed (Fig.1B). A secondary and a tertiary follicle were also observed in manatee 01S0112/31. In the ovary fragment of manatee $02 \mathrm{~S} 0112 / 60$, we detected primordial, primary, secondary, tertiary, and Graafian follicles (Fig.1C).
This organ contained a large area of bone marrow (approximately $80 \%$ of the ovary), which consisted of loose connective tissue with many adipocytes and was richly and diffusely vascularized with vessels of different calibers (Fig.1D).

At the time of the necropsy of manatee 02S0112/36, the ovaries were not found. However, we observed the presence of tissue in the left antimer, with discrete signals indicative of possible ovarian tissue. We did not find similar tissue or ovarian tissue in the right antimer. In the ovary of manatee $02 \mathrm{~S} 0112 / 36$, the cortex presented a thicker region $(403,882 \mu \mathrm{m})$ than in the ovaries of the other analyzed manatees, containing almost no follicle. In addition, this ovary presented considerable connective tissue in the supporting tissue of the cortex, where we observed a band with an intense increase in the cellularity composed of dense connective tissue and another band with less cellularity composed of loose connective tissue (Fig.1E). The ovarian marrow in manatee $02 \mathrm{~S} 0112 / 36$ was similar to that observed in the ovaries of the other analyzed manatees.

In the ovary of manatee $02 \mathrm{~S} 0112 / 77$ (supposedly an adult female), we found a large number of blood vessels, histiocytic inflammatory infiltrate (predominance of macrophages), 

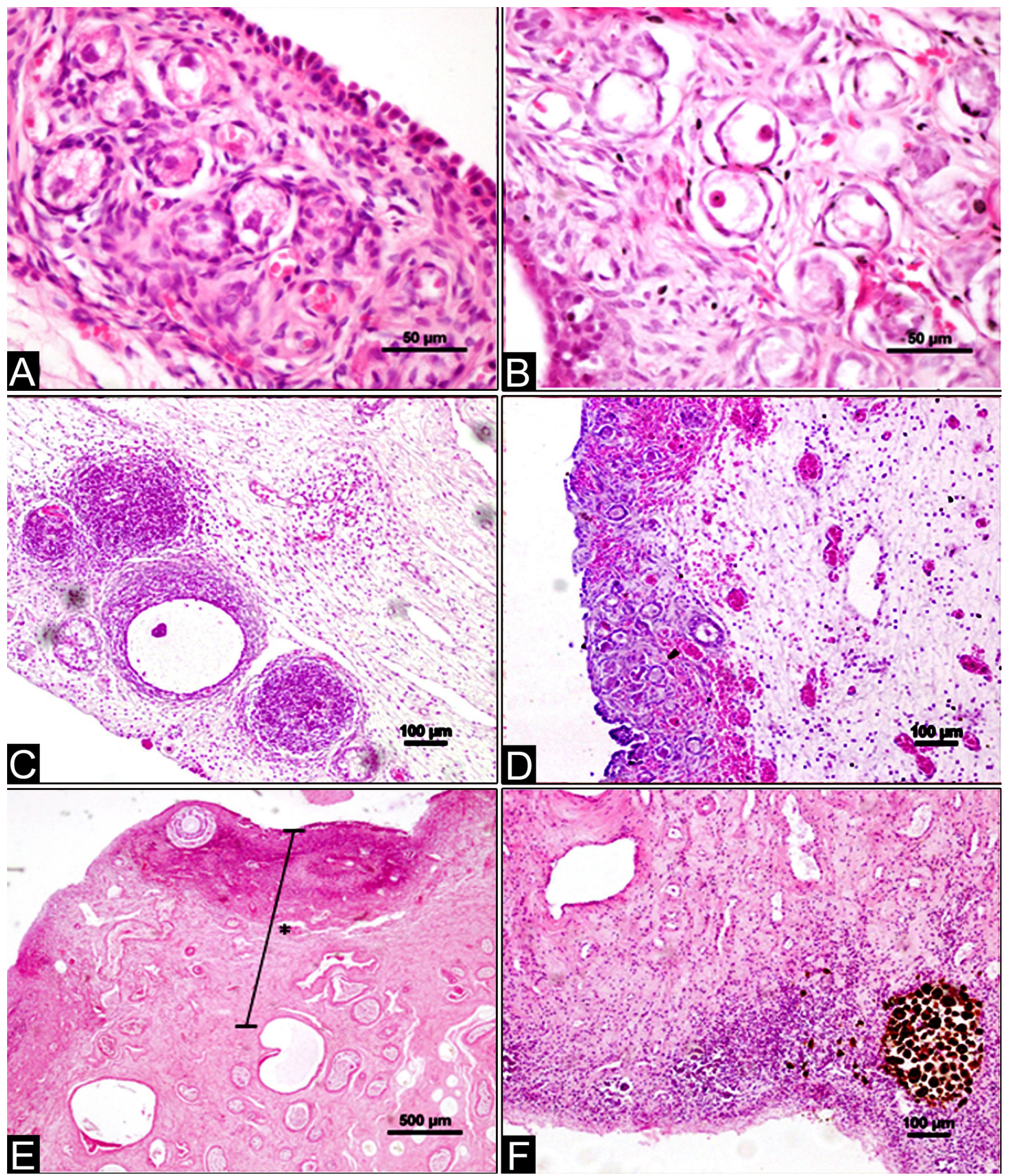

Fig.1. Ovary of Trichechus manatus. (A) Narrow cortex and germinal epithelium. HE, obj.40x. (B) Primary follicles. HE, obj.40x. (C) Tertiary follicle. HE, obj.10x. (D) Narrow cortex and large marrow area, highly vascularized. HE, obj.10x. (E) Altered ovary of manatee 02S0112/36 with thickened cortex. HE, obj.40x. (F) Ovary of manatee 02S0112/77 with an inflammatory infiltrate. HE, obj.10x.

multifocal necrosis, coalescent and congested vessels, congestion areas in the periphery, and the presence of some follicles (primary and secondary), which were in an advanced degeneration state (Fig.1F).

\section{Uterus}

The uterine mucosa was lined with simple cylindrical epithelium followed by endometrial glands with the same coating, in a perpendicular position to the mucosa. The submucosa 
Table 3. Mean \pm standard deviation (SD) of the epithelium, cortex, primordial follicle major diameter (PFMa), primordial follicle minor diameter (PFMi), primary follicle major diameter (PaFMa), primary follicle minor diameter (PaFMi), secondary follicle major diameter (SFMa), and secondary follicle minor diameter (SFMi) measured in $\mu \mathrm{m}$ in female manatees

(Trichechus manatus)

\begin{tabular}{|c|c|c|c|c|c|c|c|c|}
\hline Ovary & Epithelium & Cortex & PFMa & PFMi & PaFMa & PaFMi & SFMa & SFMi \\
\hline 01S0112/12 & 18.262 & 192.438 & 43.149 & 38.162 & 42.127 & 39.927 & ND & ND \\
\hline 08S0112/20 & 12.592 & 197.413 & 42.583 & 34.218 & 51.648 & 45.825 & ND & ND \\
\hline 01S0112/31 & 9.983 & 200.277 & 43.274 & 35.250 & 55.656 & 41.880 & ND & ND \\
\hline 02S0112/60 & 12.346 & 291.739 & 45.260 & 37.087 & 51.195 & 47.580 & 124.960 & 95.270 \\
\hline 02S0112/36 & 16.364 & 403.882 & ND & ND & ND & ND & ND & ND \\
\hline 02S0112/77 & 10.544 & 200.050 & ND & ND & ND & ND & ND & ND \\
\hline Mean \pm SD & $13.348 \pm 3.287$ & $247.633 \pm 85.363$ & $43.567 \pm 1.126$ & $36.179 \pm 1.776$ & $50.156 \pm 5.716$ & $43.803 \pm 3.516$ & $124.96 \pm 0$ & $95.27 \pm 0$ \\
\hline
\end{tabular}

was composed of abundant fibrocellular and fibrovascular tissue (Table 4). The muscular layer was composed of three layers, longitudinal, circular, and longitudinal. The serosa was composed of mesothelium-lined connective tissue. The uteri of the manatees 08S0112/20, 01S0112/12, 01S0112/31, and $02 \mathrm{~S} 0112 / 31$ were in the proliferative phase (Fig.2A). The uterus of the manatees 01S0112/30 and 02S0112/57 were in the secretory phase (Fig.2B), with glands opening into the lumen of the organ. The uterus of the manatee 02S0112/38 was in the recovery phase (Fig.2C).

\section{Placenta}

In the placenta, we detected the presence of an artery in the fetal chorion, and a vein. We also observed a well-developed villus region (lacunar region with the presence of a syncytial region, syncytiotrophoblast), and the presence of maternal tissue cells with chorionic villi (conjunctival and mesoderm). We also observed connective tissue filled with blood and maternal tissue (Fig.2D).

\section{Vagina}

The vagina presented a mucosa consisting of keratinized squamous epithelium (hyperkeratosis) with an average length of $267.1115 \mu \mathrm{m}$. The submucosa was composed of very thick and vascularized connective tissue, and areas containing longitudinal muscular glands that were also vascularized (Fig.2E).

\section{Umbilical cord}

This structure presented three vessels (two arteries, one vein) supported by loose mucous connective tissue, or Wharton jelly. These two arteries had a histological structure similar to that of other mammals, but with little definition in the middle layer. All were coated by common endothelium and exhibited an adventitious layer that was continuous with the surrounding tissue (Fig.2F).

\section{Testicles}

Manatees 02S0111/42, 02S0111/59, and 01S0111/123 were characterized as newborns owing to their body size $(1.19,1.08$, and $1.06 \mathrm{~m}$, respectively). Their testes had a structure separated by connective tissue septa, which was richly vascularized with small seminiferous tubules and had sparse cell content, namely spermatogonia and Sertoli
Table 4. Mean \pm SD of mucosal and endometrium thickness in female manatees (Trichechus manatus)

\begin{tabular}{ccc}
\hline Uterus & Mucosal $(\mu \mathrm{m})$ & Endometrium $(\mu \mathrm{m})$ \\
\hline $01 \mathrm{~S} 0112 / 12$ & 22.40 & 1338.34 \\
$08 \mathrm{~S} 0112 / 20$ & 19.03 & 1282.34 \\
$01 \mathrm{~S} 0112 / 30$ & 13.91 & 1221.82 \\
$01 \mathrm{~S} 0112 / 31$ & 14.27 & 1141.44 \\
$02 \mathrm{~S} 0112 / 38$ & 18.04 & 1282.11 \\
$02 \mathrm{~S} 0112 / 57$ & 23.86 & $\mathrm{ND}$ \\
Mean \pm SD & $18.585 \pm 4.083$ & $1253.21 \pm 74.848$ \\
ND = no data. & &
\end{tabular}

cells. The intralobular connective tissue was rich in spindle cells that sometimes formed concentric blades around the tubules (Fig.3A).

Manatee 02S0111/45 was also classified as a newborn $(1.15 \mathrm{~m})$, and the general structure of its testis was the same as that of the previously described animals, with a similar general organization of the seminiferous tubules, which were only different in size (Table 5). The intralobular stroma cells did not appear to be predominantly spindle-shaped and had a globular aspect (Fig.3B).

Manatee 02S0111/55 was classified as a juvenile manatee according to the size $(2.01 \mathrm{~m})$, and the general structure of the testis was also similar to the previous ones. However, there was a clear change in the structure of the lobe, as the seminiferous tubules were similar in size to those of manatee 02S0111/45, but with an evidently increased cell population and presence of spermatogonia, spermatocytes I and II, being characterized as an immature animal. The intralobular stroma had the appearance of mature connective tissue with observable clusters of Leydig cells that were not previously seen in the other animals (Fig.3C).

Manatee 02S0111/73 was considered an adult (3.01m) and the structure of his testis resembled that of other adult mammals. The seminiferous tubules presented a mature and organized production of spermatogonia, spermatocytes I and II, and spermatids with evident spermiogenesis, as confirmed by the presence of spermatozoa in the lumen of the seminiferous tubule. The intralobular stroma was loose and exhibited small clusters of mature Leydig cells (with vacuolized cytoplasm, Fig.3D). 

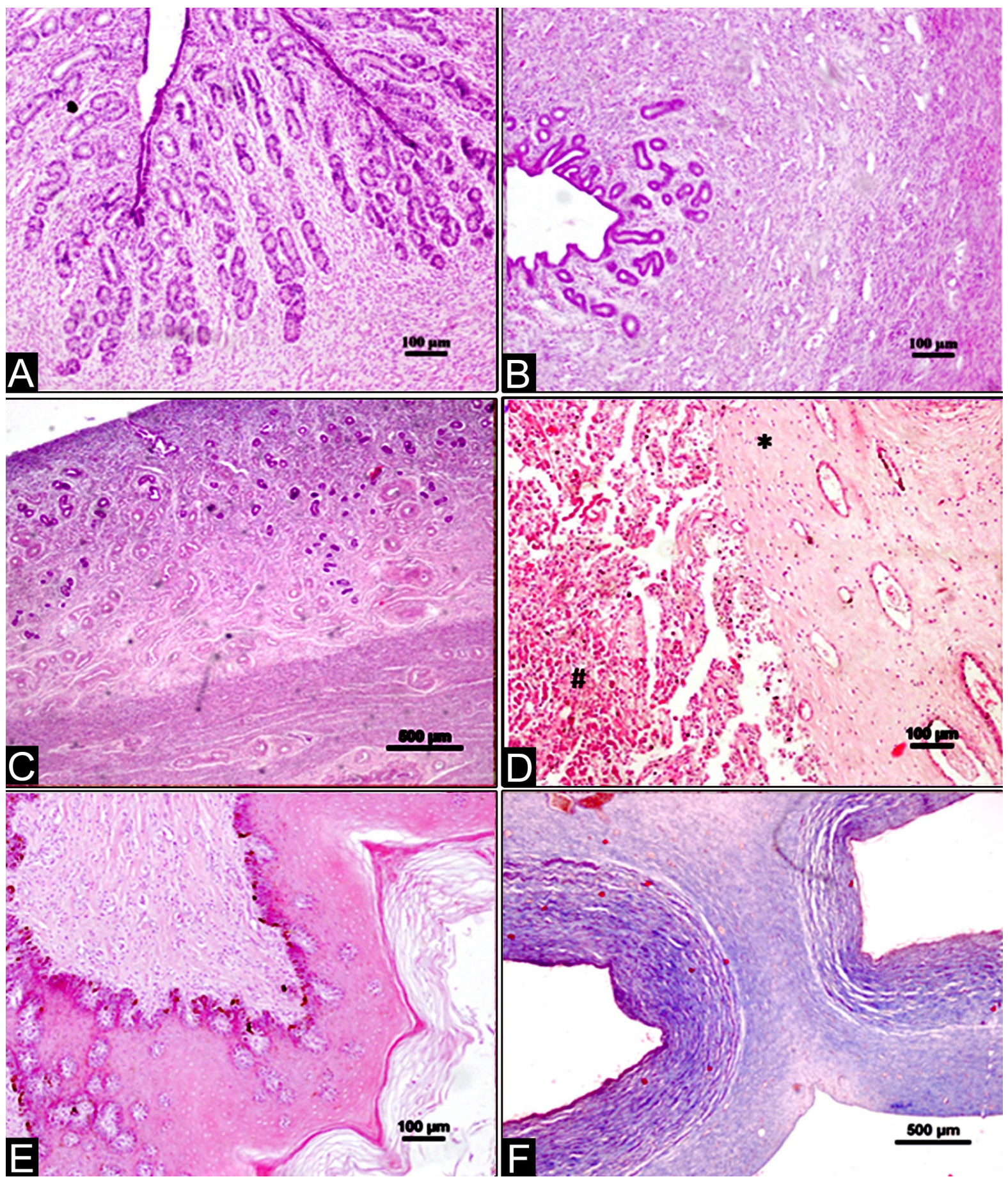

Fig.2. Uteri, placenta, vagina and umbilical cord of Trichechus manatus. (A) Uterus in the proliferative phase, with many endometrial glands. HE, obj.40x. (B) Uterus in the secretory phase, with large endometrial glands opening to the light. HE, obj.10x. (C) Uterus in the recovery phase. HE, obj.40x. (D) Placenta with chorionic villi (\#) and syncytiotrophoblast ${ }^{*}$ ). HE, obj.10x. (E) Vagina with a keratinized squamous epithelium. HE, obj.10x. (F) Umbilical cord showing the two arteries. Masson's trichrome, obj.40x.

\section{Epididymis}

In manatees 02S0111/59 and 02S0111/71, we found multiple tubular structures composed of multiple channels with variable dilation light, coated with pseudo-stratified epithelium and stereocilia, and some portions contained intraepithelial cysts. The wall was composed of abundant fibromuscular tissue, but the stroma contained loose fibromuscular tissue (Fig.3E). Manatee 02S0111/59 had a less obvious fibromuscular structure.

\section{Penis}

Manatees 02S0111/73 and 01S0111/123 presented multiple endothelium-coated vascular channels with variable dilation, filled with blood, in abundant fibromuscular support tissue 
Table 5. Mean values of the major diameter (STMa) and minor diameter (STMi) of the seminiferous tubules and mean diameter of the spermatogonia (DS) in male manatees (Trichechus manatus)

\begin{tabular}{cccc}
\hline Testicles & STMa & STMi & DS \\
\hline 02 S0111/42 & 32.692 & 26.758 & 3.642 \\
$02 \mathrm{~S} 0111 / 45$ & 46.546 & 39.854 & 4.363 \\
$02 \mathrm{~S} 0111 / 55$ & 56.437 & 42.041 & 4.624 \\
$02 \mathrm{~S} 0111 / 59$ & 39.778 & 32.692 & 4.036 \\
$02 \mathrm{~S} 0111 / 73$ & 172.345 & 134.394 & 6.162 \\
$01 \mathrm{~S} 0111 / 123$ & 35.7680 & 28.032 & ND \\
Mean \pm SD & $63.928 \pm 53.786$ & $50.629 \pm 41.494$ & $4.565 \pm 0.965$ \\
\hline ND: no data. & & &
\end{tabular}

with longitudinal, transverse, and oblique fibers. The urethral canal was lined with simple cylindrical epithelium (Fig.3F).

\section{DISCUSSION}

This is the first study providing a description of the histological characteristics of the female and male reproductive tracts of manatees (Trichechus manatus) from Brazil. Despite the publication of studies on this species in Florida, detailed descriptions of the histological characteristics of the reproductive tract are limited.

We compared the histology of the organs described in this work with that of elephants, which phylogenetically are the

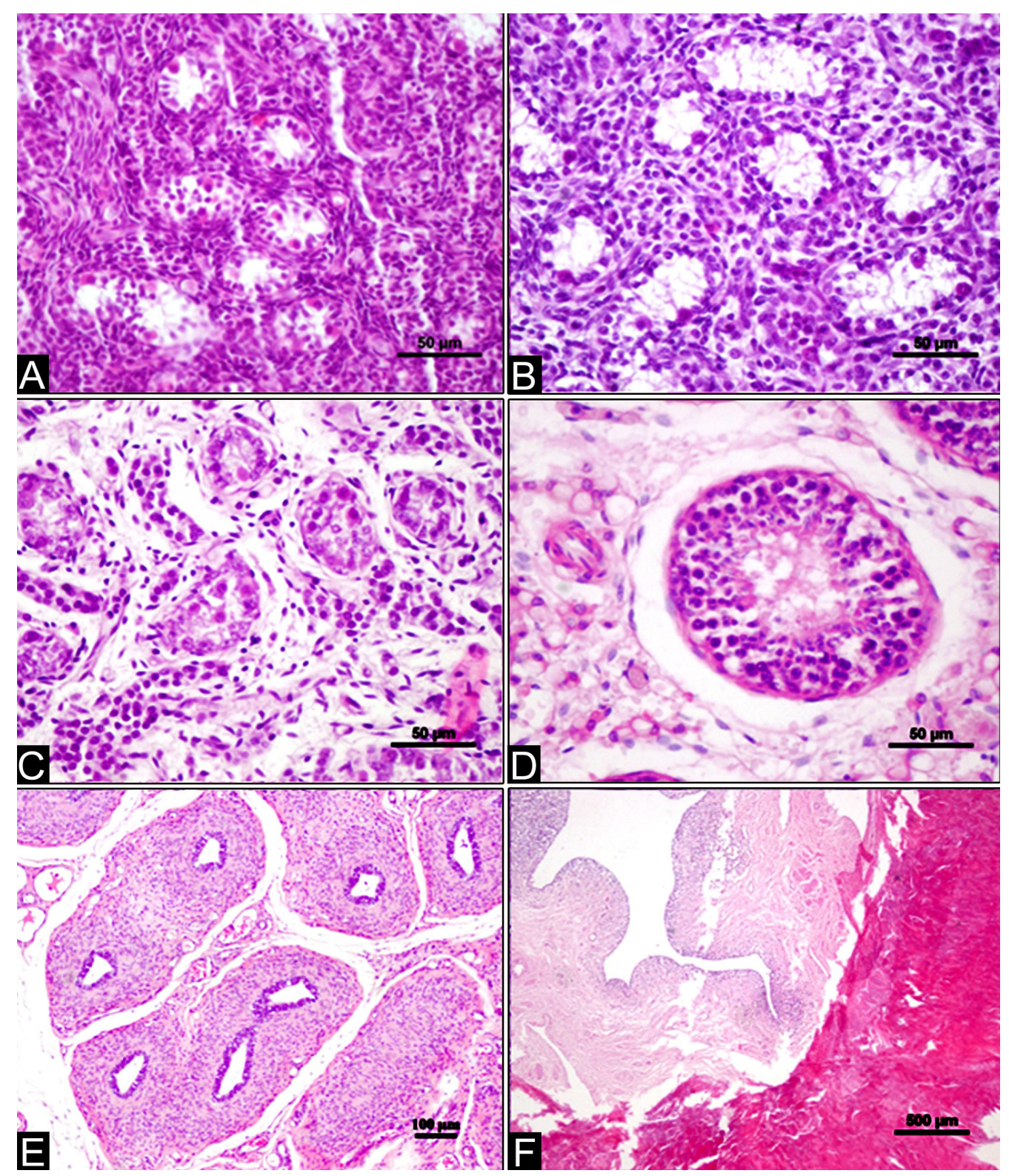

Fig.3. Testis, epididymis and penis of Trichechus manatus. (A) Testis showing the spindle cells around the seminiferous tubules. HE, obj.40x. (B) Testis showing the rounded cells around the seminiferous tubules. HE, obj.40x. (C) Testis showing spermatogonia and primary and secondary spermatocytes within the seminiferous tubules. HE, obj.40x. (D) Testis showing complete spermiogenesis within the seminiferous tubules. HE, obj.40x. (E) Epididymis with presence of intraepithelial cysts. HE, obj.10x. (F) Penis in which the cavernous space and the tunica albuginea can be observed. HE, obj.10x. 
most closely related group to sirenians, and cetaceans, as a matter of evolutionary convergence.

\section{Female reproductive tract}

At the time of necropsy of manatee 02S0112/36, we noticed the absence of ovaries and the presence of tissue in the left antimer, with discrete signs of possible ovarian tissue. Marsh \& Kasuya (1984) observed an altered ovary cortex in the short-finned pilot whale (Globicephala macrorhynchus), which presented no follicles and had reduced cortex thickness and a large amount of fibrous tissue. This female was lactating and was probably in the puerperal period. The manatee 02S0112/36 also presented a large amount of fibrous tissue in the cortex and almost no follicle, but unlike that of the short-finned pilot whale, the cortex was thicker and, during necropsy, the mammary glands had no increase in volume in the axillary region, or milk.

The uteri of manatees 08 S0112/20 and 01S0112/12 were in the proliferative phase, but these animals were neonates, so this characteristic was probably owing to the action of maternal hormones. The uteri of manatees 01S0112/31 and $02 \mathrm{~S} 0112 / 31$ were in a proliferative phase, presenting a well-developed epithelium, increased endometrial glands, increased density near the myometrium, and similar features to those of non-pregnant adult female elephants (Hanks \& Short 1972).

The uterus of manatee $02 \mathrm{~S} 0112 / 38$ was in the recovery phase and belonged to a lactating female, according to the characterization at the time of the necropsy. Histologically, the uterus of this female manatee resembled the uterus of an African elephant female (Loxodonta africana) in lactational anestrous, presenting small endometrial glands and low density near the myometrium (Hanks \& Short 1972). Coincidentally, one week after the registration of this female, a live newborn was found stranded in the same place. Genetic studies confirmed the relationship between the two animals (Silva 2015).

The placenta was similar to that of Amazonian manatees with a well-developed villus region, syncytiotrophoblast, and the presence of maternal tissue cells and chorionic villi. The umbilical cord was similar to that of $T$. inunguis (Carter et al. 2008).

\section{Male reproductive tract}

The general histological appearance of the male reproductive tract in T. manatus was similar to that of the African elephant (L. africana) and the common dolphin (Delphinus delphis). The histological characteristics of the testis were similar to those described for testes of mature and immature animals in Florida manatees (Hernandez et al. 1995).

Murphy et al. (2005) described four stages of testis development in $D$. delphis, and in our work three similar phases were observed. We noticed the immature phase, marked by abundant interstitial tissue and the presence of few spermatogonia; the pubertal stage, in which there is a reduction of the interstitial tissue and a small increase in the diameter of the seminiferous tubules with spermatogonia and spermatocyte; the mature young phase (not observed in this work), which is characterized by the increase of the diameter of the seminiferous tubules and the presence of a central and small lumen; and the sexually mature phase, marked by the presence of spermatozoa, thus confirming complete spermatogenesis.

According to the classification mentioned above, it was possible to observe that cubs 02S0111/42, 02S0111/45, $02 \mathrm{~S} 0111 / 59$, and 01S0111/123 were in the immature phase. The juvenile manatee $02 \mathrm{~S} 0111 / 55$ was in the pubertal stage and the adult manatee $02 \mathrm{~S} 0111 / 73$ was in the mature phase.

We observed that the mean diameter of the seminiferous tubules varied with the age and size of the manatee, and that smaller and younger animals had smaller, larger tubule diameters, whereas older animals showed larger tubule diameters, similar to what is observed in cetaceans and elephants (Short et al. 1967, Murphy et al. 2005, Westgate \& Read 2007).

We also found similarities between the epididymis of the samples studied in this study and the efferent tubules in L. africana, which were composed of a ciliary pseudo-stratified epithelium. However, there were no spermatozoids observed in the epididymides, because they belonged to young animals (Short et al. 1967).

\section{CONCLUSIONS}

The systematic study of the different components of the reproductive tract, at different stages of growth and sexual development, is necessary to provide a complete profile of the histological characteristics of the reproductive tracts of male and female manatees.

It should be noted that this work appears to be the first to describe the histological characteristics of the tissues of the reproductive tract, placenta, and umbilical cord in this species, which present similar features to those of other aquatic mammals.

The present study seems to contribute significantly to current knowledge of the reproductive histology of the manatee.

Acknowledgements.- We would like to thank the Association for Research and Preservation of Aquatic Ecosystems (Associação de Pesquisa e Preservação de Ecossistemas Aquáticos - Aquasis) of Caucaia, Ceará, and the National Center for Research and Conservation of Aquatic Mammals (Centro Nacional de Pesquisa e Conservação de Mamíferos Aquáticos - CMA/ICMBio) of Itamaracá, Pernambuco, for providing the biological material necessary for this work. We thank Dr. Daniel de Araújo Viana, PhD for the help with the testicles histological descriptions. We also would like to thank for the support of Conselho Nacional de Desenvolvimento Científico e Tecnológico (149051/2015-8 to A.R.B., 305420/2013-5 to L.D.M.S.).

\section{REFERENCES}

Alves M.D., Kinas P.G., Marmontel M., Borges J.C.G., Costa A.F., Schiel N. \& Araújo M.E. 2016. First abundance estimate of the Antillean manatee (Trichechus manatus manatus) in Brazil by aerial survey. J. Mar. Biol. Assoc. U.K. 96(04):955-966. <http://dx.doi.org/10.1017/S0025315415000855>

Attademo F.L.N., Balensiefer D.C., Bôaviagem Freire A.C., Sousa G.P., Cunha F.A.G.C. \& Luna F.O. 2015. Debris ingestion by the Antillean Manatee (Trichechus manatus manatus). Mar. Pollut. Bull. 101(1):284-287. <http:// dx.doi.org/10.1016/j.marpolbul.2015.09.040> <PMid:26431561>

Brasil 2014. Portaria MMA no 444, de 17 de dezembro de 2014. Available at <http://www.icmbio.gov.br/portal/images/stories/biodiversidade/ faunabrasileira/avaliacao-do-risco/PORTARIA_N\%C2\%BA_444_de_17_ de_dezembro_2014.pdf> Accessed on Dec. 7, 2017. 
Carter A.M., Miglino M.A., Ambrósio C.E., Santos T.C.D., Rosas F.C.W., d’Afonseca Neto J.A., Lazzarini S.M., Carvalho A.F. \& Silva V.M.F. 2008. Placentation in the Amazonian manatee (Trichechus inunguis). Reprod. Fertil. Develop. 20(4):537-545. <http://dx.doi.org/10.1071/RD08009><PMid:18462617>

Geraci J.R., Lounsbury V.J. \& Nathan J. 2005. Marine Mammals Ashore: a field guide for strandings. 2nd ed. College Station, Texas A\&M Sea Grant Publication, Texas. 382p.

Hanks J. \& Short R.V.1972. The formation and function of the corpus luteum in the African elephant, Loxodonta africana. J. Reprod. Fertil. 29(1):79-89. <http://dx.doi.org/10.1530/jrf.0.0290079> <PMid:5017016>

Hernandez P., Reynolds 3rd J.E., Marsh H. \& Marmontel M. 1995. Age and seasonality in spermatogenesis of Florida manatees, p.84-97. In: O'Shea T.J., Ackerman B.B. \& Percival H.F. (Eds), Population Biology of the Florida Manatee. National Biological Service, Fort Collins.

Lima R.P., Paludo D., Soavinski R.J., Silva K.G. \& Oliveira E.M.A. 2011. Levantamento da distribuição, ocorrência e status de conservação do PeixeBoi Marinho (Trichechus manatus, Linnaeus, 1758) no litoral nordeste do Brasil. Nat. Resour. 1:41-57.

Marmontel M. 1995. Age and reproduction in female Florida manatees, p.98-119. In: O’Shea T.J., Ackerman B.B. \& Percival H.F. (Eds), Population Biology of the Florida Manatee. National Biological Service, Information and Technology Report, Fort Collins.

Marsh H. \& Kasuya T. 1984. Changes in the ovaries of the short-finned pilot Whale, Globicephala macrorhynchus, with age and reproductive activity. Rep. Int. Whal. Commn. 6(Special issue):311-335.

Marsh H., O’Shea T.J. \& Reynolds 3rd J.E. 2011. Ecology and Conservation of the Sirenia: dugongs and manatees. Cambridge University Press, Cambridge. 521p. <http://dx.doi.org/10.1017/CB09781139013277>.
Meirelles A.C.O. 2008. Mortality of the Antillean manatee, Trichechus manatus manatus, in Ceará State, north-eastern Brazil. J. Mar. Biol. Assoc. U.K. 88(06):1133-1137. <http://dx.doi.org/10.1017/S0025315408000817>

Meirelles A.C.O. \& Carvalho V.L. 2016. Peixe-boi marinho: biologia e conservação no Brasil. Aquasis, Bambu Editora e Artes Gráficas, São Paulo. 176p.

Murphy S., Collet A. \& Rogan E. 2005. Mating strategy in the male common dolphin (Delphinus delphis): what gonadal analysis tells us. J. Mammal. 86(6):1247-1258.<http://dx.doi.org/10.1644/1545-1542(2005)86[1247:MS ITMC]2.0.CO;2>

Parente C.L., Vergara-Parente J.E. \& Lima R.P. 2004. Strandings of Antillean manatees, Trichechus manatus manatus, in northeastern Brazil. Lat. Am. J. Aquat. Mamm. 3(1):69-75. <http://dx.doi.org/10.5597/lajam00050>

Reynolds III J.E., Rommel S.A. \& Bolen M.E. 2002 Anatomical dissection: thorax and abdomen, p.21-30. In: Perrin W.F., Wursig B. \& Thewissen J.G.M. (Eds), Encyclopedia of Marine Mammals. Academic Press, Massachussets.

Rodrigues F.R., Silva V.M.F., Barcellos J.F.M. \& Lazzarini S.M. 2008. Reproductive anatomy of the female Amazonian manatee Trichechus inunguis Natterer, 1883 (Mammalia: Sirenia). Anat. Rec. 291(5):557-564. <http://dx.doi. org/10.1002/ar.20688> <PMid:18383272>

Short R.V., Mann T. \& Hay M.F. 1967. Male reproductive organs of the African elephant, Loxodonta africana. J. Reprod. Fertil. 13(3):517-536, NP. <http:// dx.doi.org/10.1530/jrf.0.0130517><PMid:6029179>

Silva S.M. 2015. Caracterização populacional e estimativa de parentesco entre peixes-boi marinhos Trichechus manatus (Linnaeus, 1758) usando marcadores microssatélites. Dissertação de Mestrado em Biologia Ambiental, Universidade Federal do Pará, Pará.

Westgate A.J. \& Read A.J. 2007. Reproduction in short-beaked common dolphins (Delphinus delphis) from the western North Atlantic. Mar. Biol. 150(5):1011-1024. <http://dx.doi.org/10.1007/s00227-006-0394-1> 